\title{
Long-term Atmospheric Mercury Wet Deposition at Underhill, Vermont
}

\author{
GERALD J. KEELER,* LYNNE E. GRATZ AND KHALID AL-WALI \\ University of Michigan Air Quality Laboratory, Ann Arbor, 48109 MI, USA
}

Accepted 4 December 2004

\begin{abstract}
Section 112(m) of the 1990 Clean Air Act Amendments, referred to as the Great Waters Program, mandated an assessment of atmospheric deposition of hazardous air pollutants (HAPs) to Lake Champlain. Mercury ( $\mathrm{Hg}$ ) was listed as a priority HAP and has continued to be a high priority for a number of national and international programs. An assessment of the magnitude and seasonal variation of atmospheric $\mathrm{Hg}$ levels and deposition in the Lake Champlain basin was initiated in December 1992 which included event precipitation collection, as well as collection of vapor and particle phase $\mathrm{Hg}$ in ambient air. Sampling was performed at the Proctor Maple Research Center in Underhill Center, VT. The range in the annual volume-weighted mean concentration for $\mathrm{Hg}$ in precipitation was $7.8-10.5 \mathrm{ng} / 1$ for the 11 -year sampling period and the average amount of $\mathrm{Hg}$ deposited with each precipitation event was $0.10 \mu \mathrm{g} / \mathrm{m}^{2}$. The average amount of $\mathrm{Hg}$ deposited through precipitation each year from 1993 to $2003 \mathrm{was} 9.7 \mu \mathrm{g} / \mathrm{m}^{2} / \mathrm{yr}$. A seasonal pattern for $\mathrm{Hg}$ in precipitation is clearly evident, with increased $\mathrm{Hg}$ concentrations and deposition observed during spring and summer months. While a clear trend in the 11-year event deposition record at Underhill was not observed, a significant decrease in the event max-to-monthly ratio was observed suggesting that a major source influence was controlled over time. Discrete precipitation events were responsible for significant fractions of the monthly and annual loading of $\mathrm{Hg}$ to the forested ecosystem in Vermont. Monthly-averaged temperatures were found to be moderately correlated with monthly volumeweighted mean $\mathrm{Hg}$ concentrations $\left(r^{2}=0.61\right)$ and $\mathrm{Hg}$ deposition $\left(r^{2}=0.67\right)$ recorded at the Vermont site. Meteorological analysis indicated the highest levels of $\mathrm{Hg}$ in precipitation were associated with regional transport from the west, southwest, and south during the warmer months.
\end{abstract}

Keywords: trends; seasonal patterns; speciation; photochemistry

\section{Introduction}

Mercury $(\mathrm{Hg})$ is a toxic bioaccumulative substance found in aquatic ecosystems. Atmospheric deposition is widely recognized as an important link in the cycling of $\mathrm{Hg}$ in the environment (Lindqvist and Rhode, 1985; Mierle, 1990; Fitzgerald et al., 1991; Iverfeldt, 1991). Lake Champlain, located in the

*To whom correspondence should be addressed:

Tel.: + 1-734-936-1836

E-mail: jkeeler@umich.edu northeastern United States on the border between northern New York State, Vermont, and Quebec, has been designated as one of the "Great Waters" by the 1990 Clean Air Act Amendments (CAA). The Great Waters Program was established in Section $112(\mathrm{~m})$ of the CAA to identify and assess atmospheric deposition of hazardous air pollutants (HAPs) to the Great Lakes, Chesapeake Bay, Lake Champlain and coastal waters. Mercury $(\mathrm{Hg})$ is one of the 189 HAPs identified in this section of the CAA. Requirements of the Great Waters program 
include: (a) establishing atmospheric deposition stations to monitor deposition of HAPs within the Lake Champlain watershed, (b) determining the role of atmospheric deposition in the pollutant loading for the lake, and (c) investigating the sources of air pollutants deposited in the watershed.

Mercury concentrations exceeding fish consumption advisory limits have been documented for certain sport fish, and elevated levels of $\mathrm{Hg}$ and PCBs have been found in the sediments at many sites within Lake Champlain including those in the deep lake (McIntosh, 1994). This report identified several lake-wide issues for future investigation, including the critical need to better understand how contaminants like $\mathrm{Hg}$ and $\mathrm{PCBs}$ are entering Lake Champlain. More recently the New England Governors and Canadian Premiers (2003) have identified that $\mathrm{Hg}$ releases to the environment with "resulting public health and environmental impacts" need to be addressed.

Atmospheric deposition has been implicated as a primary source of $\mathrm{Hg}$ to remote lakes in the Great Lakes region (Fitzgerald et al., 1991; Swain et al., 1992). Atmospheric $\mathrm{Hg}$ deposition has also been shown to play a significant role in $\mathrm{Hg}$ loading to fresh water ecosystems and watersheds in Vermont and New England (Scherbatskoy et al., 1994, 1998; Kamman and Engstrom, 2002). While atmospheric deposition of acidic species and transport of these pollutants from the Midwest to New England has been documented (Butler et al., 1991), relatively few studies have documented the transport and deposition of $\mathrm{Hg}$ to northern New England (Scherbatskoy et al., 1994; Burke et al., 1995; Macolm et al., 2003). These $\mathrm{Hg}$ studies were all part of a coordinated long-term study of $\mathrm{Hg}$ cycling in the Lake Champlain watershed. Here we report on the only long-term event precipitation $\mathrm{Hg}$ data collected in the New England region, and the factors that influenced the atmospheric concentrations and deposition of this persistent, bioaccumulative contaminant.

\section{Collection and analysis methods}

\section{Clean technique and acid cleaning procedure}

Precipitation samples were processed and analyzed in a Class 100 clean room at the University of
Michigan to avoid potential contamination. Clean room suits and particle-free gloves were worn at all times during preparation and analysis of samples. All field and analytical supplies used in the collection and analysis of $\mathrm{Hg}$ and trace element samples were prepared using an 11-day acidcleaning procedure (Landis and Keeler, 1997) to ensure that all materials that potentially came in contact with a sample were essentially $\mathrm{Hg}$-free. Standard operating procedures included bottle blank determinations, which ensured that sampling bottles were $\mathrm{Hg}$-free before they were used in the field. Furthermore, the entire precipitation sampling train, for both $\mathrm{Hg}$ and trace elements, was replaced with a freshly acid-cleaned set after each precipitation event.

\section{Wet deposition sampling}

The sampling site is located on the west slope of Mount Mansfield at the Proctor Maple Research Center (PMRC) at $400 \mathrm{~m}$ elevation. The PMRC is located in the Lake Champlain basin approximately $25 \mathrm{~km}$ east of the lake. No major urban or industrial areas exist within $200 \mathrm{~km}$ of the site. Wet-only event precipitation samples were collected using a modified MIC-B (MIC, Thornhill, Ontario) automatic precipitation collector (Landis and Keeler, 1997). During the first 2 years of the study samples were collected into a 101 borosilicate glass (BSG) vessel using the MIC-B with a Teflon-coated funnel which had an inlet area of $0.2 \mathrm{~m}^{2}$ (Hoyer et al., 1995). Samples were transferred from the 101 BSG vessel into a 11 BSG bottle immediately after collection. This approach was found to be difficult to implement on a large scale and the glass bottles were not as desirable due to breakage during shipment. Glass bottles were also not considered the best material for the collection of the other trace elements. In early summer of 1994 the system described in Landis and Keeler (1997) replaced the original one and remains in use. Enrichment and adsorption of trace metals in precipitation was minimized by the use of separate $\mathrm{Hg}$ and trace element sampling trains composed of different materials (Ross, 1986, 1990). The Hg sampling train was comprised of a borosilicate glass funnel (collection area of $191 \pm 9 \mathrm{~cm}^{2}$ ), and a Teflon adapter, which 
incorporated a glass vapor lock, attached to a 11 Teflon sample bottle. The trace element sampling train was comprised of a polypropylene funnel (collection area of $167 \pm 7 \mathrm{~cm}^{2}$ ) and a polypropylene adapter attached to a 1-1 polypropylene sample bottle. The collection of $\mathrm{Hg}$ and trace elements directly into separate sample bottles was also important due to the absorptive behavior of trace metals in precipitation to the walls of the bottles (Church et al., 1984). While samples for both trace elements and $\mathrm{Hg}$ were collected for each event, only the long-term $\mathrm{Hg}$ record is reported in this manuscript.

Mercury samples were oxidized with concentrated $\mathrm{BrCl}$ to a $1 \%$ solution $(\mathrm{v} / \mathrm{v})$ and were stored in a dark cold room before being analyzed. Post oxidation of the $\mathrm{Hg}$ samples and acidification of the trace element samples to a $\mathrm{pH}<1.5$ prohibits absorptive loss to the container walls (Subramanian et al., 1978; Scudlark et al., 1991). The sampling trains were supported in the UM Modified MIC-B collector by a UM custom-built acrylic insert. The volume of each precipitation sample was determined gravimetrically. Precipitation events $\geq 0.1 \mathrm{~cm}$ in depth were efficiently collected by the $M I C-B$. Precipitation only overflowed the collection bottle for relatively large events $>5.6 \mathrm{~cm}$. The funnels had high vertical sides to aid in efficient collection and to prevent loss due to "bounce off" during intense rain. In addition, the sampling trains were designed to be light so they could be easily removed, disassembled and acid cleaned. During the coldest months of the year (November-April) a small ceramic space heater $(750 \mathrm{~W})$ was installed inside the base of the collector to maintain a cabinet temperature of $\sim 10{ }^{\circ} \mathrm{C}$ to melt snow that collected in the funnels and prevent collected samples from freezing. A Belfort precipitation gauge provided a continuous record of the precipitation received at the Underhill site. The precipitation depth for the first 2-years of the study was determined directly from the Belfort charts, and in subsequent years the volume of precipitation collected in the glass funnel and the area of the collection funnel was used to calculate the precipitation depth. The Belfort precipitation gauge also provided the actual rain amount in the rare event that the 1-1 sample bottles overflowed due to extreme rain events.
The total $\mathrm{Hg}$ concentration in precipitation was determined by purging $\mathrm{Hg}$ from solution onto a gold-coated bead trap using a $\mathrm{Hg}$-free nitrogen stream after pre-reduction of $\mathrm{BrCl}$ with $\mathrm{NH}_{2} \mathrm{OH}$, and reduction of divalent $\mathrm{Hg}$ by $\mathrm{SnCl}_{2}$ to elemental gaseous $\mathrm{Hg}\left(\mathrm{Hg}^{0}\right)$. Total $\mathrm{Hg}$ was quantified by a dual amalgamation technique followed by cold-vapor atomic fluorescence spectrometry (CVAFS) (Landis and Keeler, 1997). Co-located total $\mathrm{Hg}$ samples were collected using identical samplers and protocols as part of the Lake Michigan Mass Balance Study (LMMBS). The LMMBS ran concurrently for 18-months with the long-term monitoring conducted at the Underhill site. An absolute mean difference of $8.1 \%$ was calculated between the co-located samples (Landis and Keeler, 1997). Analytical precision of laboratory replicates during this study was $95.5 \%$.

\section{Meteorological trajectory analysis}

The transport of air to the Underhill site was estimated using the Hybrid Single-Particle Lagrangian Integrated Trajectory (HYSPLIT) Model Version 4.6 (Draxler and Hess, 1997). HYSPLIT 72-h back trajectories were calculated using input data from The National Weather Service's National Center for Environmental Prediction (NCEP) Nested Grid Model (NGM) for 1993-1996 and the Eta Data Assimilation System (EDAS) for 1997-2003. The NGM and EDAS data were obtained from a standard data archive maintained by the National Oceanic and Atmospheric Administration's Air Resources Laboratory (NOAA-ARL). NOAA-ARL routinely archives NGM and EDAS data in a format that can be read by the HYSPLIT Modeling System.

The hour of maximum precipitation measured from each event was used as the start time for the trajectory calculation. The starting height for each trajectory was calculated as one-half the mixing height determined from the upper-air soundings. Surface and upper air meteorological maps obtained from the National Weather Service (NWS) were used to explore the validity of the calculated trajectories and to better understand the type of precipitation (convective, frontal, etc.) that was received. 


\section{Results}

\section{Event wet deposition}

The University of Michigan Air Quality Laboratory (UMAQL) has operated the only long-term event precipitation sites in the United States, which began in the early 1990s. Precipitation collection at the PMRC site began in December 1992 and has continued without interruption to the present. The concentration of $\mathrm{Hg}$ measured in event samples (shown in Fig. 1) includes data for the 11 -year period from $1 / 1 / 1993$ to $12 / 31 / 2003$. Event precipitation concentrations varied by over two orders of magnitude with a range in individual measured event concentrations of $\sim 0.9-90 \mathrm{ng} / 1$. The volume-weighted mean (VWM) concentration for the data shown was $8.9 \mathrm{ng} / \mathrm{l}(N=1111)$. The average event, over the 11-years, had a precipitation depth of $1.1 \mathrm{~cm}$ and a maximum depth of $6.2 \mathrm{~cm}$.

While $\mathrm{Hg}$ concentrations were influenced by the volume of precipitation collected, the precipitation depth could only explain approximately $20 \%$ of the variance in the $\mathrm{Hg}$ concentration. Other factors such as the season, type of precipitation, and meteorological transport history more strongly influenced the $\mathrm{Hg}$ concentration observed at Underhill. The occurrence of precipitation events with relatively low concentrations $(<2.0 \mathrm{ng} / \mathrm{l})$ was independent of the precipitation volume collected, suggesting that under certain conditions little $\mathrm{Hg}$ was available to be removed or the chemical form of the $\mathrm{Hg}$ was not amenable to washout or rainout processes.

The atmospheric loading of $\mathrm{Hg}$ to Underhill from 1993 to 2003 is shown in the event deposition plot (Fig. 2). Wet deposition was calculated, on an event basis, by taking the product of the $\mathrm{Hg}$ concentration (shown in Fig. 1) and the precipitation depth. Event $\mathrm{Hg}$ deposition varied from $\sim 0.002 \mu \mathrm{g} / \mathrm{m}^{2}$ to $1.8 \mu \mathrm{g} / \mathrm{m}^{2}$ with the average event wet deposition for the 11-year time period being $0.10 \mu \mathrm{g} / \mathrm{m}^{2}$.

The importance of individual precipitation events to the monthly and yearly $\mathrm{Hg}$ deposition was clearly seen in the 11-year record. The single largest deposition event, which delivered $1.8 \mu \mathrm{g} / \mathrm{m}^{2}$, was recorded at Underhill on 21 October 2003. This unusual event was the product of a $5.1 \mathrm{~cm}$ rain, associated with a low pressure system sitting over northern New York State, with an above average $\mathrm{Hg}$ concentration of $35.1 \mathrm{ng} / 1$. High pressure centered over central Pennsylvania on 20 October 2003 resulted in stagnation and low-mixing heights over western New York, Pennsylvania, Ohio, and southern Ontario. Air mass transport into northern New York and Vermont, ahead of the warm front attached to

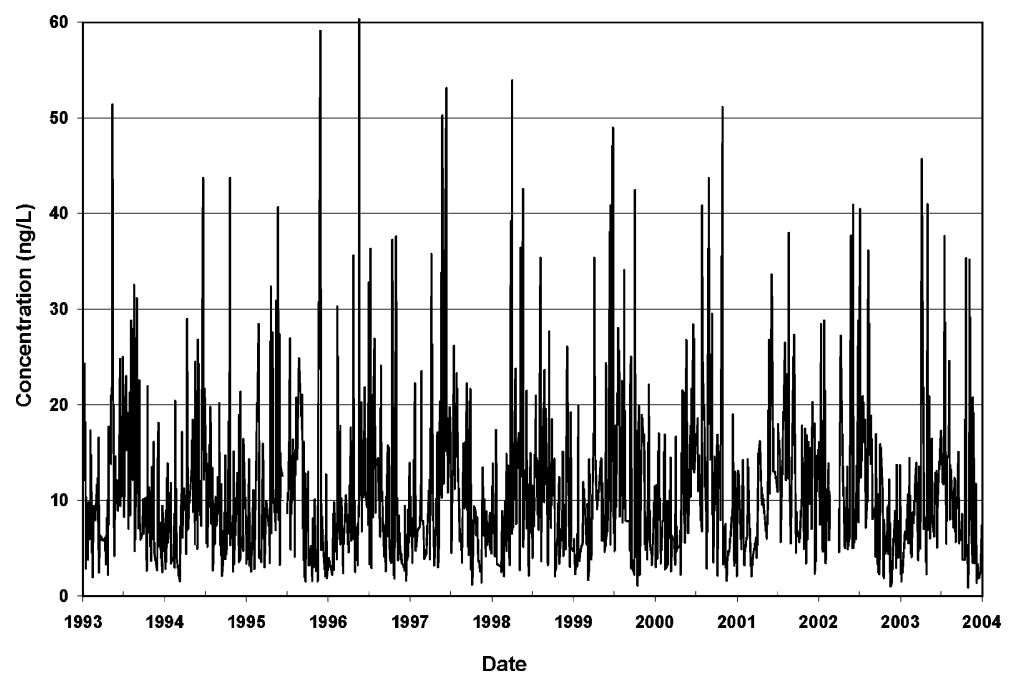

Figure 1. Event Hg concentrations measured at Underhill, Vermont from 1993-2003. 


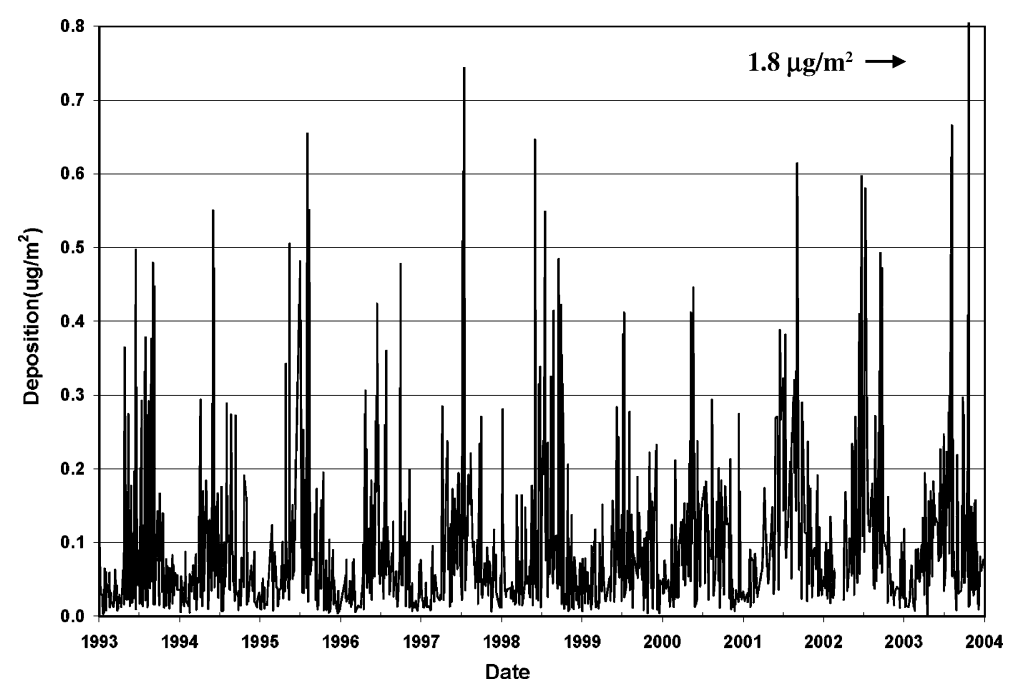

Figure 2. Event Hg deposition measured at Underhill, VT from 1993-2003.

the low pressure system, was from the westsouthwest from the areas of stagnation on the previous day. Interestingly, a large precipitation event with $5.3 \mathrm{~cm}$ of rainfall was also recorded only 5 days earlier, but had a below average concentration of $3.8 \mathrm{ng} / \mathrm{l}$, resulting in a $\mathrm{Hg}$ deposition of only $0.2 \mu \mathrm{g} / \mathrm{m}^{2}$. These single large deposition events $\left(>0.4 \mu \mathrm{g} / \mathrm{m}^{2}\right)$ can account for $20-60 \%$ of the monthly deposition, $5-17 \%$ of the total annual deposition recorded at this site, and $13 \%$ of the total $\mathrm{Hg}$ deposition recorded at the Underhill site over the 11-year period.

A significant trend was not evident in the maximum event $\mathrm{Hg}$ deposition, or the arithmetic mean deposition, over the 11 years of observation reported here. Interestingly, there was a statistically significant decrease (19\%) in the maximum event deposition to monthly mean deposition ratio over the 11 years $\left(r^{2}=0.37\right)$. A similar decrease in the max-to-monthly mean $\mathrm{Hg}$ concentration ratio was also observed $\left(r^{2}=0.28\right)$ perhaps suggesting that a source of the elevated event $\mathrm{Hg}$ concentrations and deposition has been controlled. A meaningful examination of the chemical and meteorological parameters that control the removal of $\mathrm{Hg}$ species from the atmosphere requires the precipitation samples to be collected in discrete events (Sisterson et al., 1985; Ross, 1990; Dvonch et al., 1999).

\section{Seasonal variability}

The key to understanding the spatial and temporal patterns in atmospheric deposition lies in our ability to explain the seasonality in $\mathrm{Hg}$ deposition. The event $\mathrm{Hg}$ deposition data, shown in Fig. 2, displays clear seasonal trends. Higher $\mathrm{Hg}$ deposition, typically observed during the warmer months, was likely the result of a mix of meteorological, source emission, and atmospheric chemistry influences. For example, it is widely known that the concentrations of oxidants such as ozone, $\mathrm{OH}$ radicals, and acids that oxidize gaseous $\mathrm{Hg}^{0}$ to gaseous $\mathrm{Hg}^{2+}$ are higher during warmer months and would lead to elevated concentrations of $\mathrm{Hg}^{2+}$ (Schroeder and Menthe, 1998; Lin and Pekonen, 1999). Scavenging of soluble gaseous $\mathrm{Hg}^{2+}$ has also been pointed to as more efficient in summertime precipitation events than winter due to differences in the cloud microphysical processing between rain and frozen precipitation (Hoyer et al., 1995; Keeler et al., 1997). The warmer months also had a higher baseline (minimum values) in the event $\mathrm{Hg}$ deposition than the colder months as seen in Fig. 2. The lowest concentrations and total wet deposition were seen in winter months, and highest values appeared in the spring and summer months. This may, in part, indicate the role of convective transport of $\mathrm{Hg}$ to 
this region, and may also be reflective of the types of clouds and storms that bring precipitation to northern Vermont during the summer relative to the winter. The 11-year plot for total monthly $\mathrm{Hg}$ wet deposition recorded at the PMRC site is shown in Fig. 3. The monthly volume-weighted concentration plot, not shown, looked similar to the deposition plot with similar monthly trends and year-to-year differences in the monthly concentrations.

While little year-to-year difference was observed in the minimum monthly $\mathrm{Hg}$ wet deposition, the maximum monthly total varied greatly from year to year. Calendar year 1998 was a particularly significant year for $\mathrm{Hg}$ wet deposition. This was largely due to three well-above average deposition months (June-August) during the spring-summer period which recorded large individual events $\left(>0.4 \mu \mathrm{g} / \mathrm{m}^{2}\right)$ in each of the months. There did not, however, appear to be an overall increase or decrease in the $\mathrm{Hg}$ concentrations over time. This will be examined more closely in the subsequent discussion.

The seasonal variability in $\mathrm{Hg}$ concentrations and $\mathrm{Hg}$ deposition has been reported in previous studies in North America (Burke et al., 1995; Hoyer et al., 1995; Landis and Keeler, 1997) and Europe (Iverfeldt, 1991). The larger data set from Underhill provides a clearer picture of how the $\mathrm{Hg}$ levels fluctuate seasonally over the 11 annual cy- cles. The seasonal pattern in the atmospheric $\mathrm{Hg}$, with highest precipitation concentrations and wet deposition typically seen in the summer and lowest concentrations and wet deposition in the winter, was believed partly to be the result of increased convection during the warmer summer months which can increase the ability of the air to transport $\mathrm{Hg}$ over longer distances, and leads to greater precipitation amounts that remove $\mathrm{Hg}$ from the atmosphere. This may also indicate the role of precipitation type in the amount of $\mathrm{Hg}$ wet deposition, as rain may have a greater capacity to scavenge and hold different forms of $\mathrm{Hg}$ than snow.

To examine the relationship between concentration and season, we calculated the frequency distribution for the 11-year event precipitation record. Fig. 4 shows the frequency distribution for $\mathrm{Hg}$ concentrations in each season over the 11-year period. For each sample collected, the number of samples that fell into each concentration bin, $0-5,5-10,10-15,15-20$, etc. was determined and then subdivided into the time of year that the sample was collected. Event samples that were collected between 1993-2003 were most often $(>31 \%)$ in the $5-10 \mathrm{ng} / \mathrm{l}$ concentration range and were just as likely to be collected in any of the four seasons. The next most frequent concentrations observed were in the $0-5 \mathrm{ng} / 1$ range with the majority of these samples from the autumn and

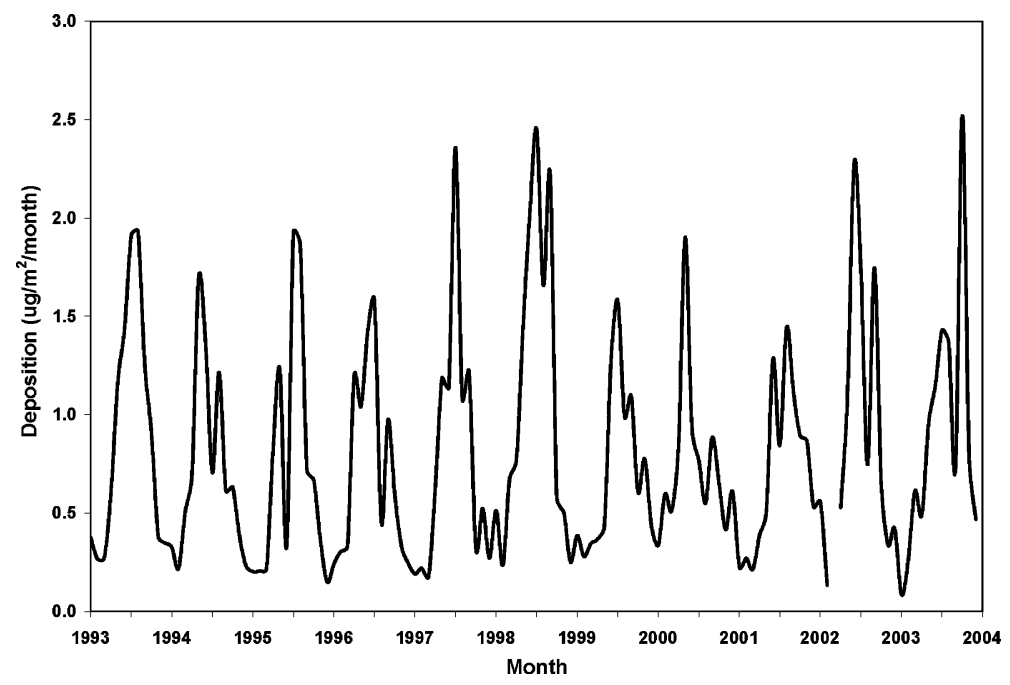

Figure 3. Monthly Total $\mathrm{Hg}$ wet deposition at Underhill, VT. 


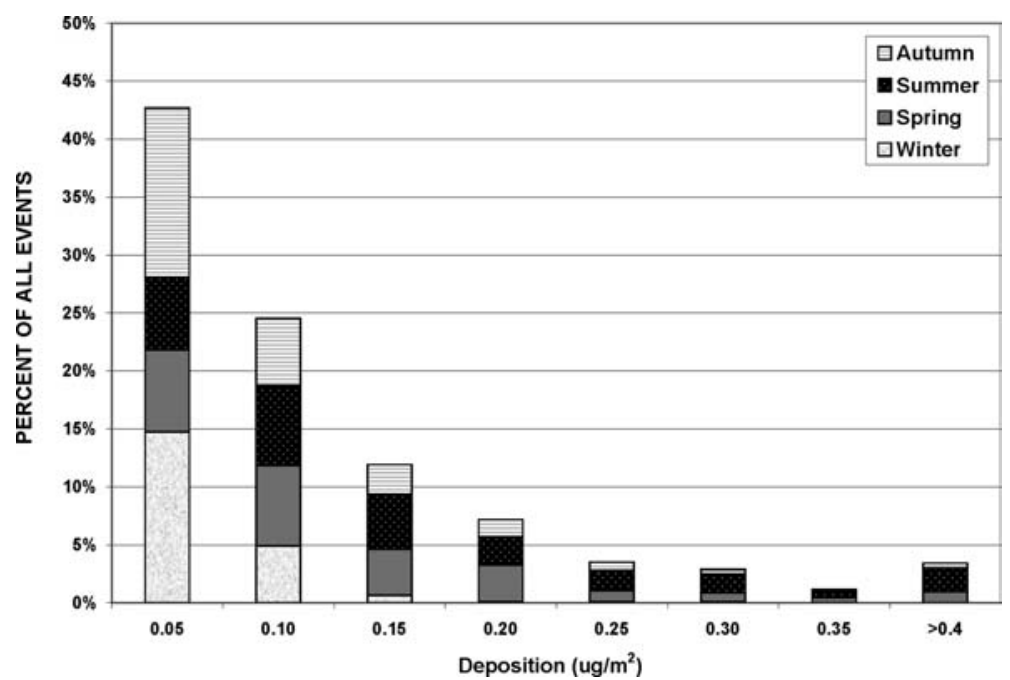

Figure 4. Frequency distribution of seasonal $\mathrm{Hg}$ concentration measured in precipitation at Underhill, VT from 1993-2003 $(N=1111)$

winter seasons. The highest concentrations of $\mathrm{Hg}$ were more common during the spring and summer seasons rather than in winter or autumn. Samples collected during the summer were more likely to have concentrations in the $10-15 \mathrm{ng} / 1$ range.

The frequency distribution for $\mathrm{Hg}$ measured in event wet deposition samples for each season is shown in Fig. 5. Lower $\mathrm{Hg}$ wet deposition amounts were more frequent during the autumn and winter, and higher $\mathrm{Hg}$ values were typically present during the spring and summer. The majority $(>43 \%)$ of all event samples collected resulted in $\mathrm{Hg}$ deposition in the range $0-0.05 \mu \mathrm{g} / \mathrm{m}^{2}$ with another $25 \%$ of the events having values in the $0.05-0.1 \mu \mathrm{g} / \mathrm{m}^{2}$ range. Less than $5 \%(N=39)$ of the event samples resulted in $\mathrm{Hg}$ deposition $>0.4 \mu \mathrm{g} / \mathrm{m}^{2}$, however, these events contributed to $19 \%$ of the total deposition recorded at the

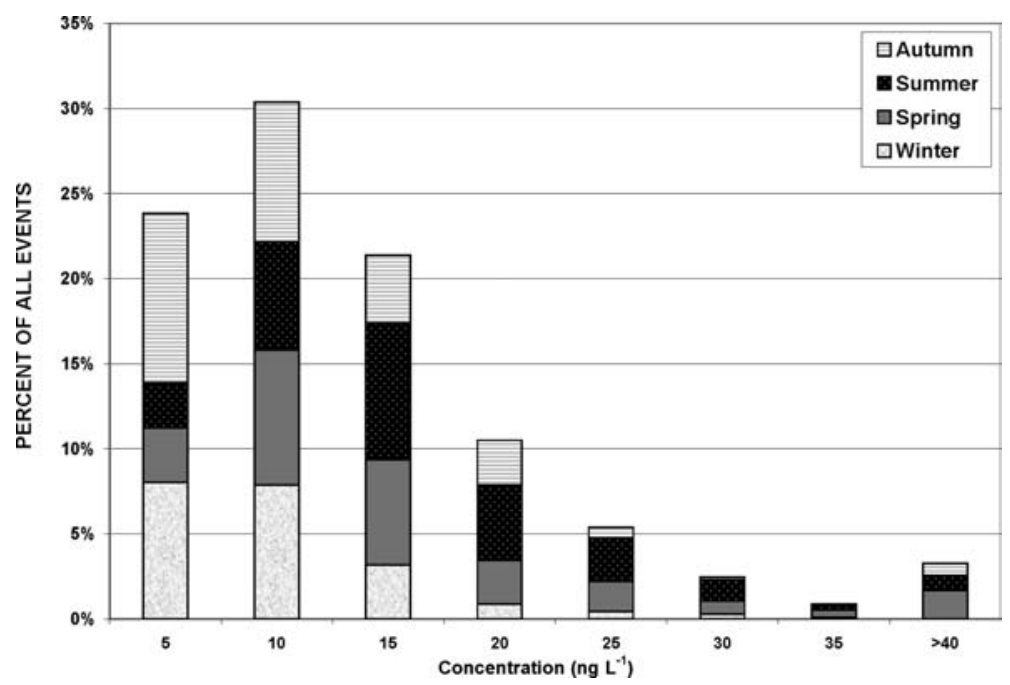

Figure 5. Frequency distribution of seasonal $\mathrm{Hg}$ wet deposition measured in precipitation at Underhill, VT from 1993-2003 $(N=1111)$ 
Underhill site over the 11-year period. Each of these events had both above average $\mathrm{Hg}$ concentrations as well as above average precipitation depths. All of the 39 precipitation events that resulted in $\mathrm{Hg}$ deposition values above $0.4 \mu \mathrm{g} / \mathrm{m}^{2}$ were in the form of rain. Of these events, 24 fell during the summer months, 11 during the spring and 4 during the autumn. These high levels of $\mathrm{Hg}$ were much less frequent, but point to the importance of atmospheric chemistry, cloud microphysics, and transport during the spring and summer months. It was the frequency of these elevated $\mathrm{Hg}$ deposition events that resulted in above average annual deposition amounts. Thus, understanding these events may lead to a better understanding of the year-to-year patterns in deposition.

\section{Annual variability}

Considerable sample to sample variability observed in the daily event data can be explained largely by variations in the meteorological processes and source-receptor relationships that influence the concentrations and deposition of $\mathrm{Hg}$. Studies assessing changes in atmospheric deposition over time scales longer than seasons suggest that short-term meteorological variability is less significant than longer-term climatic variability (Bradley, 1986). While long-term trends in $\mathrm{Hg}$ deposition may be more strongly influenced by climatic fluctuations, the importance of large events appears to be quite significant in controlling the annual levels of atmospheric $\mathrm{Hg}$ deposition at the northern Vermont site.

The annual volume-weighted mean (VWM) $\mathrm{Hg}$ concentration and total $\mathrm{Hg}$ wet deposition collected at the Underhill site are summarized in Table 1. The number of events collected $(>0.1 \mathrm{~cm})$ each year of sampling at Underhill ranged from 71 to 124 over the 11-years of observation (See Table 1). The maximum values in any column are shown in bold for emphasis. While the number of events per year varied, on average, by only $15 \%$ from the 11-year mean, the type and intensity of the events were quite different, resulting in precipitation depths that varied by more than a factor of two. The number of small events that were not collected for analysis also varied considerably from year to year with the average number equal to 13 , and a range of 4-27 small events per year. The years 2000, 2002, and 2003 all recorded more than 25 precipitation events $<0.1 \mathrm{~cm}$ in precipitation depth.

The data in Table 1 indicate that 1998 was a particularly significant year for precipitation, totaling $141 \mathrm{~cm}$. The year 2003 also shows a high precipitation total of $133 \mathrm{~cm}$. Although these two years had similar precipitation amounts, there were many more events in 1998 than in 2003. The year 1998 recorded 123 events while 2003 saw only 90 , indicating a greater intensity of the events in 2003. In addition, 1993 and 1998 both received 124

Table 1. Annual volume-weighted mean (VWM) $\mathrm{Hg}$ concentration and total $\mathrm{Hg}$ wet deposition from event samples collected at Underhill, VT from 1993-2003

\begin{tabular}{|c|c|c|c|c|c|c|c|}
\hline Year & $\begin{array}{l}\text { Precipitation } \\
\text { depth }(\mathrm{cm})\end{array}$ & $\begin{array}{l}\text { Total } \mathrm{Hg} \\
\text { wet deposition } \\
\left(\mu \mathrm{g} / \mathrm{m}^{2}\right)\end{array}$ & $\begin{array}{l}\text { Average } \mathrm{Hg} \\
\text { wet deposition } \\
\left(\mu \mathrm{g} / \mathrm{m}^{2}\right)\end{array}$ & $\begin{array}{l}\text { VWM Hg } \\
\text { concentration } \\
(\mathrm{ng} / \mathrm{l})\end{array}$ & $\begin{array}{l}\text { \# events } \\
\text { collected }\end{array}$ & $\begin{array}{l}\text { Maximum } \\
\text { concentration (ng/l) }\end{array}$ & $\begin{array}{l}\text { Maximum } \\
\text { deposition }\left(\mu \mathrm{g} / \mathrm{m}^{2}\right)\end{array}$ \\
\hline 1993 & 103.2 & 10.8 & 0.09 & 10.5 & 124 & 51.4 & 0.50 \\
\hline 1994 & 97.9 & 8.6 & 0.08 & 8.8 & 115 & 43.7 & 0.55 \\
\hline 1995 & 105.9 & 8.7 & 0.09 & 8.2 & 99 & 59.1 & 0.66 \\
\hline 1996 & 102.7 & 8.4 & 0.08 & 8.2 & 102 & 89.8 & 0.48 \\
\hline 1997 & 97.2 & 9.3 & 0.10 & 9.6 & 98 & 53.1 & 0.74 \\
\hline 1998 & 141.1 & 13.3 & 0.11 & 9.5 & 124 & 53.9 & 0.65 \\
\hline 1999 & 109.1 & 8.6 & 0.08 & 7.8 & 107 & 49.0 & 0.41 \\
\hline 2000 & 105.5 & 9.0 & 0.10 & 8.5 & 95 & 51.1 & 0.45 \\
\hline 2001 & 85.0 & 8.6 & 0.12 & 10.1 & 71 & 38.0 & 0.61 \\
\hline 2002 & 118.9 & 10.2 & 0.12 & 8.6 & 85 & 40.9 & 0.60 \\
\hline 2003 & 133.1 & 10.9 & 0.12 & 8.2 & 91 & 45.7 & 1.79 \\
\hline MEAN & 109.1 & 9.7 & 0.10 & 8.9 & 101 & 52.3 & 0.68 \\
\hline
\end{tabular}


events, the highest of any year. However, 1998 recorded a much higher precipitation total, implying that the 1998 events were more intense that the 1993 events. In contrast, 2001 had both lowest yearly precipitation depth $(85 \mathrm{~cm})$ and the smallest number of events (71).

The volume-weighted mean $\mathrm{Hg}$ concentration varied over each year as well, with a maximum value of $10.0 \mathrm{ng} / 1$ calculated for 2001 and a minimum of $7.8 \mathrm{ng} / 1$ in 1999. The volume-weighted mean for all years was $8.7 \mathrm{ng} / \mathrm{l}$ and the average total $\mathrm{Hg}$ deposition for the eleven-year period was $9.7 \mu \mathrm{g} / \mathrm{m}^{2}$. It is important to note the high volumeweighted mean concentrations in 1993, 1997, 1998, and 2001. While 1998 received the highest precipitation of any year over the 11-years, 1997 and 2001 received less than average $(=109.1 \mathrm{~cm})$ precipitation amounts. During 1998, $13.3 \mu \mathrm{g} / \mathrm{m}^{2}$ of $\mathrm{Hg}$ deposition was recorded, and this was also the second highest deposition year for sulfate, nitrate, chloride, and other major ions in precipitation reported by the National Acid Deposition Program (NADP). However, unlike the apparent downward trend in sulfate deposition at Underhill, the annual $\mathrm{Hg}$ levels observed at Underhill show variation from year to year without a clear increasing or decreasing trend. To further understand the possible causes for the seasonal and annual variations, the $\mathrm{Hg}$ data was compared with other long-term $\mathrm{Hg}$ records, as well as with the on-site meteorological data and the upwind history of each event determined by back trajectories.

\section{Comparison with other long-term event records}

Recognizing that long-term precipitation records are essential for establishing trends and understanding the impacts of changes in $\mathrm{Hg}$ emissions, the UMAQL also collected a decade of event precipitation data at three sites in Michigan (Dexter, Pellston, and Eagle Harbor) for the period 1994-2003. Over this 10-year deposition record, a clear decreasing gradient from south to north was observed in Michigan. The 10 -year $\mathrm{Hg}$ deposition total recorded at Underhill from 19942003 compared closely with the Pellston site $\mathrm{Hg}$ deposition, as the two sites collected 96 versus $92 \mu \mathrm{g} / \mathrm{m}^{2}$, respectively. The deposition at these two sites was greater than the deposition observed at
Eagle Harbor, on the shores of Lake Superior, which was $58 \mu \mathrm{g} / \mathrm{m}^{2}$, but lower than the deposition measured at Dexter, MI of $120 \mu \mathrm{g} / \mathrm{m}^{2}$ for the 10 years. While the year-to-year variability in the deposition was, on average, $18 \%$ at the Michigan sites, the 10-year variability observed at Underhill was only $12 \%$. Interestingly, there was not an obvious trend in the $\mathrm{Hg}$ deposition at three Michigan sites (Keeler and Dvonch, 2004) or at the Vermont site over the 10 years from 19942003. While there have been attempts to control emissions within the region and nationally over the past decade (Butler et al., 2001), the MI data illustrates the consistent long-term impact that sources in the southern part of the Great Lakes region have had on $\mathrm{Hg}$ deposition across the Great Lakes Basin.

\section{Temperature dependence}

The monthly-averaged $\mathrm{Hg}$ data was examined in relationship to temperature data obtained from the meteorological tower at the Proctor Maple Research Center. Temperatures for each day with a precipitation event were averaged monthly for comparison with the monthly VWM Hg concentration and monthly total wet deposition data. Figure 6 displays the average temperature (line) and average $\mathrm{Hg}$ deposition (bars) for each month over the 11-year period. This figure suggests that the monthly variation in the temperature strongly influences the processes that control the deposition of $\mathrm{Hg}$ from the atmosphere. As previously mentioned, the transport of $\mathrm{Hg}$ may be higher with warmer temperatures due to increased convection and mixing. The plot shows that higher levels of $\mathrm{Hg}$ were deposited during the warmer, more photochemically active summer months, and lower amounts of $\mathrm{Hg}$ were deposited in the colder months. A significant relationship between monthly temperature and $\mathrm{Hg}$ wet deposition was observed with an $r^{2}$ value of 0.67 .

In addition, the on-site meteorological data, including the hourly temperature measurements, were averaged for each day of precipitation. While the monthly averaged temperature and monthly $\mathrm{Hg}$ deposition were moderately correlated, this relationship was not as clear when we matched the daily averaged temperature with the resulting daily-event $\mathrm{Hg}$ deposition. This implies that either 


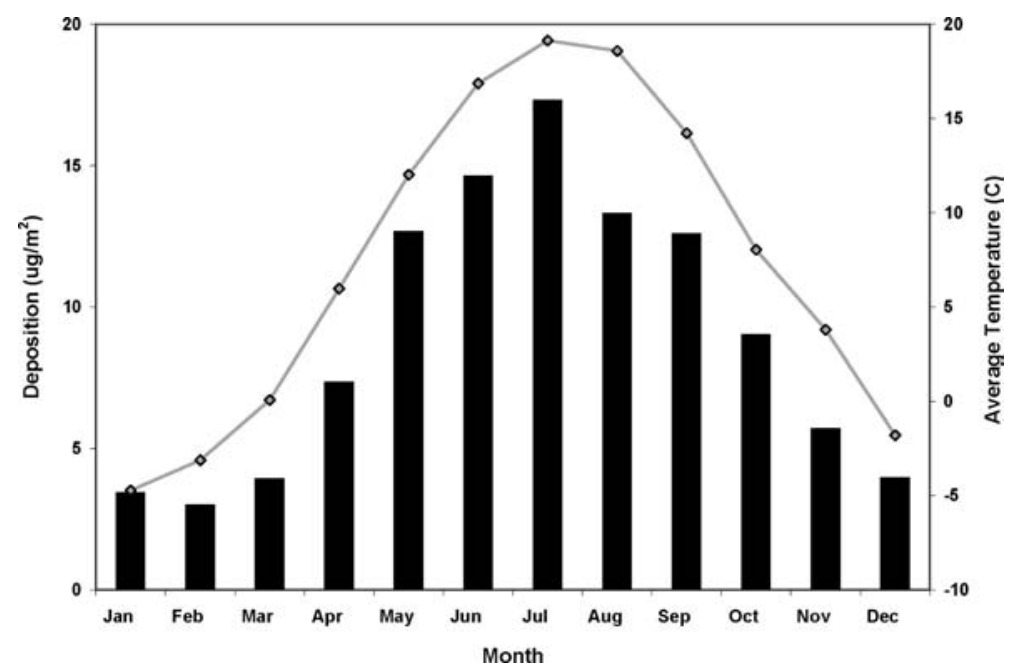

Figure 6. Monthly total $\mathrm{Hg}$ wet deposition and monthly average temperatures (line).

that the meteorological parameters and atmospheric chemistry that varied seasonally largely control the deposition of $\mathrm{Hg}$, or that the upwind temperature and conditions are more important than the temperatures that were recorded on the days that precipitation was collected.

\section{Back trajectory analysis}

The importance of the large deposition events on the long-term loading of $\mathrm{Hg}$ to the northern Vermont site was discussed earlier in this paper. To further understand the transport of these high levels of $\mathrm{Hg}$, HYSPLIT 72-h back trajectories were calculated for each day of the year. Trajectories associated with precipitation events that resulted in $\mathrm{Hg}$ deposition $>0.4 \mu \mathrm{g} / \mathrm{m}^{2}$ are shown in Fig. 7. A summary of each of the precipitation events, including the date, $\mathrm{Hg}$ concentration, precipitation depth, and total $\mathrm{Hg}$ deposition is provided in Table 2 .

While the meteorological and source-receptor relationships that were associated with the highest deposition events may be complex, the fact that they largely fell into west-southwest and southerly transport corridors gives us insights into the factors controlling $\mathrm{Hg}$ levels and removal from the atmosphere. Poirot et al., 2001 found similar transport and source-receptor relationships using hybrid receptor modeling techniques applied to aerosol data from the PMRC site. They identified the southerly source area as East Coast Oil and the southwesterly source area as a Midwest coal source contribution to the aerosol concentrations measured at Underhill. Each of the events shown had above average $\mathrm{Hg}$ concentrations as well as an above average precipitation depth. While air mass transport from the northwest and southeast was also found to bring elevated concentrations of $\mathrm{Hg}$ to the Vermont site (Burke et al., 1995), transport from this corridor was generally not associated with the highest $\mathrm{Hg}$ deposition events over the 11-year record. Results from hybrid-receptor modeling techniques applied to the long-term event $\mathrm{Hg}$ deposition data are forthcoming and should help to identify the dominant source areas contributing to the deposition of $\mathrm{Hg}$ in Vermont.

\section{Conclusion}

The 11-year record at Underhill, VT is the longest event-based $\mathrm{Hg}$ precipitation data set in the United States. The event wet deposition data reveals strong monthly and seasonal trends that imply significant dependence on meteorological conditions throughout the year. The data reveals a temperature dependence that supports the monthly and seasonal variations. The annual analysis indicates little variation in the average transport of $\mathrm{Hg}$ to the Underhill region over time, and thus no simple trend 


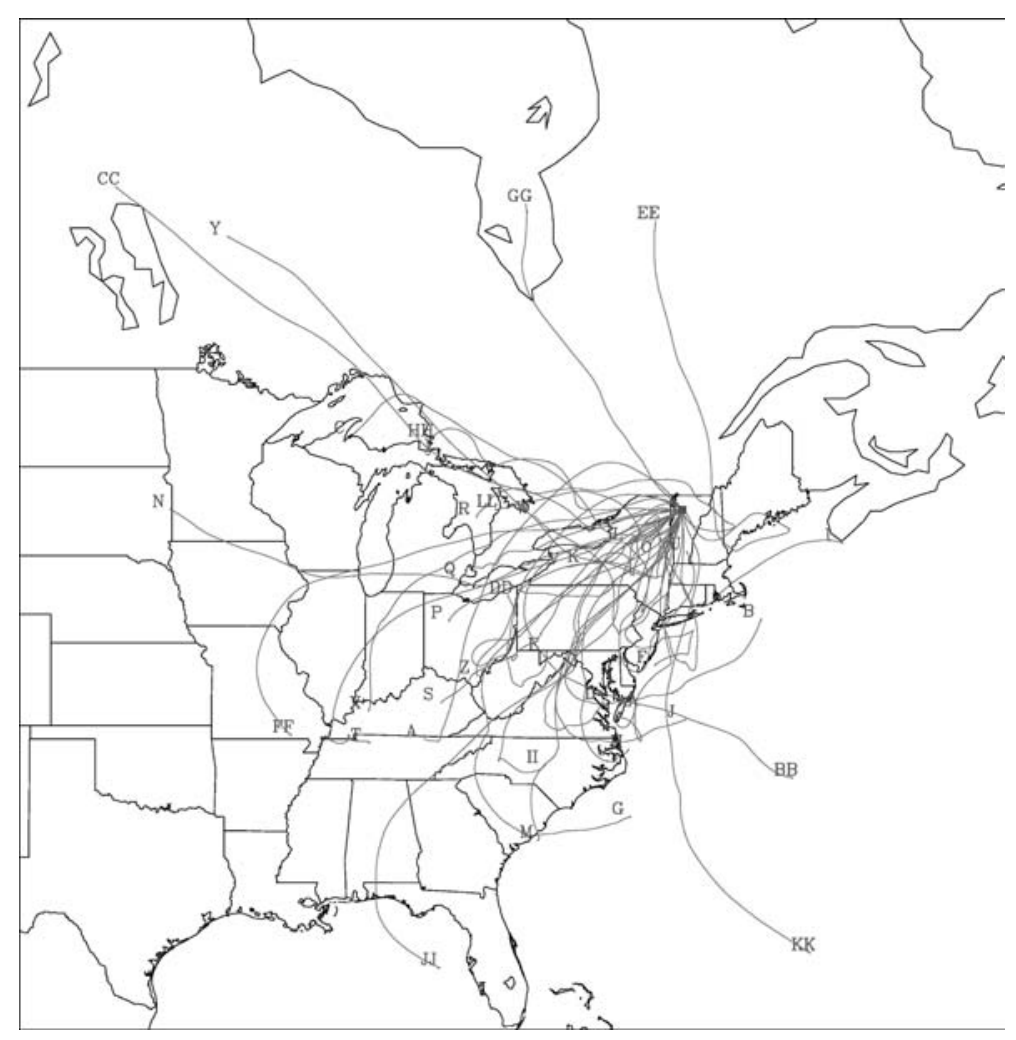

Figure 7. Back-trajectories associated with precipitation events with deposition events $>0.4 \mu \mathrm{g} / \mathrm{m}^{2}$ from Underhill, VT for 19932003.

was discerned in the 11-year deposition record. Large deposition events significantly contributed, as much as $17 \%$, to the annual $\mathrm{Hg}$ deposition total. It is also apparent that the primary source regions are to the west and southwest of Underhill, VT based on meteorological back-trajectory analysis. Analysis of archived precipitation samples by ICPMS for trace element concentrations combined with the previously discussed $\mathrm{Hg}$ wet deposition data will further our understanding of the atmospheric sources and transport to Northern New England. In addition, a more thorough investigation of the meteorology associated with each event and an indepth examination of the back-trajectories will also be vital to understanding the atmospheric transport and source-receptor relations for $\mathrm{Hg}$. Hybrid receptor models applied to this data will provide a detailed apportionment of the $\mathrm{Hg}$ deposition, indicating the most important sources and source regions contributing to the $\mathrm{Hg}$ burden at the northern Vermont site.

\section{Acknowledgements}

The mercury research and long-term $\mathrm{Hg}$ record was initiated by Dr. Timothy Scherbatskoy working collaboratively with the UMAQL and we thank him for his leadership and friendship over the years. This research was primarily sponsored by the Cooperative Institute of Limnology and Ecosystem Research (CILER) under cooperative agreements from the Environmental Research Laboratory (ERL), National Oceanic and Atmospheric Administration (NOAA), U.S. Department of Commerce. Additional support was provided by the USEPA Great Waters Program, Northeast States for Coordinated Air Management (NESCAUM), and EPA Region I. The authors would like to thank the dedicated students and staff of the UMAQL for their contributions to the research at the PMRC and this project including: Marion Hoyer, Lisa Cleckner, Tim Dvonch, Alan Vette, Ann Rea, Janet Burke, 
Table 2. Top deposition events $\left(>0.4 \mu \mathrm{g} / \mathrm{m}^{2}\right)$ at the PMRC site from 1993-2003

\begin{tabular}{|c|c|c|c|c|}
\hline $\begin{array}{l}\text { Trajectory } \\
\text { ID }\end{array}$ & $\begin{array}{l}\text { Event } \\
\text { start } \\
\text { date }\end{array}$ & $\begin{array}{l}\text { Precipitation } \\
\text { depth }(\mathrm{cm})\end{array}$ & $\begin{array}{l}\mathrm{Hg} \\
\text { concentration } \\
(\mathrm{ng} / \mathrm{l})\end{array}$ & $\begin{array}{l}\text { Hg wet } \\
\text { deposition } \\
\left(\mu \mathrm{g} / \mathrm{m}^{2}\right)\end{array}$ \\
\hline A & $4 / 25 / 1993$ & 2.1 & 17.7 & 0.4 \\
\hline $\mathrm{B}$ & $6 / 15 / 1993$ & 2.0 & 24.8 & 0.5 \\
\hline $\mathrm{C}$ & $7 / 29 / 1993$ & 1.8 & 21.3 & 0.4 \\
\hline $\mathrm{D}$ & $8 / 24 / 1993$ & 3.6 & 10.4 & 0.4 \\
\hline $\mathrm{E}$ & $8 / 31 / 1993$ & 4.4 & 10.8 & 0.5 \\
\hline $\mathrm{F}$ & $9 / 9 / 1993$ & 2.0 & 22.6 & 0.4 \\
\hline G & $5 / 31 / 1994$ & 2.4 & 23.0 & 0.6 \\
\hline $\mathrm{H}$ & $6 / 6 / 1994$ & 3.9 & 12.0 & 0.5 \\
\hline $\mathrm{I}$ & $5 / 14 / 1995$ & 1.6 & 30.9 & 0.5 \\
\hline $\mathbf{J}$ & $7 / 1 / 1995$ & 5.6 & 8.7 & 0.5 \\
\hline $\mathrm{K}$ & $8 / 3 / 1995$ & 6.0 & 11.0 & 0.7 \\
\hline $\mathrm{L}$ & $8 / 11 / 1995$ & 2.7 & 20.8 & 0.6 \\
\hline M & $6 / 13 / 1996$ & 3.8 & 11.2 & 0.4 \\
\hline $\mathrm{N}$ & $7 / 26 / 1996$ & 2.4 & 15.0 & 0.4 \\
\hline $\mathrm{O}$ & $9 / 28 / 1996$ & 3.1 & 15.5 & 0.5 \\
\hline $\mathrm{P}$ & $7 / 9 / 1997$ & 4.9 & 12.3 & 0.6 \\
\hline Q & $7 / 14 / 1997$ & 3.5 & 21.1 & 0.7 \\
\hline $\mathrm{R}$ & $7 / 15 / 1997$ & 2.0 & 26.2 & 0.5 \\
\hline $\mathrm{S}$ & $5 / 31 / 1998$ & 4.9 & 13.1 & 0.6 \\
\hline Not Shown & $7 / 16 / 1998$ & 2.6 & 21.0 & 0.5 \\
\hline $\mathrm{T}$ & $8 / 24 / 1998$ & 2.3 & 17.7 & 0.4 \\
\hline $\mathrm{U}$ & $9 / 15 / 1998$ & 5.2 & 9.4 & 0.5 \\
\hline $\mathrm{V}$ & $9 / 26 / 1998$ & 2.3 & 18.5 & 0.4 \\
\hline $\mathrm{W}$ & 9/30/1998 & 2.6 & 13.4 & 0.4 \\
\hline $\mathrm{X}$ & $7 / 5 / 1999$ & 4.4 & 8.7 & 0.4 \\
\hline $\mathrm{Y}$ & $7 / 9 / 1999$ & 2.3 & 17.8 & 0.4 \\
\hline $\mathrm{Z}$ & $5 / 8 / 2000$ & 4.9 & 8.5 & 0.4 \\
\hline AA & $5 / 18 / 2000$ & 1.7 & 26.8 & 0.4 \\
\hline $\mathrm{BB}$ & $6 / 16 / 2001$ & 3.0 & 13.0 & 0.4 \\
\hline $\mathrm{CC}$ & $7 / 10 / 2001$ & 2.6 & 14.8 & 0.4 \\
\hline DD & $8 / 31 / 2001$ & 5.0 & 12.2 & 0.6 \\
\hline $\mathrm{EE}$ & $6 / 11 / 2002$ & 4.9 & 8.4 & 0.4 \\
\hline $\mathrm{FF}$ & $6 / 21 / 2002$ & 3.9 & 15.5 & 0.6 \\
\hline GG & $7 / 5 / 2002$ & 2.6 & 15.2 & 0.4 \\
\hline $\mathrm{HH}$ & $7 / 8 / 2002$ & 4.7 & 12.4 & 0.6 \\
\hline II & $9 / 14 / 2002$ & 4.0 & 12.3 & 0.5 \\
\hline JJ & $9 / 22 / 2002$ & 4.4 & 10.6 & 0.5 \\
\hline KK & $8 / 4 / 2003$ & 4.6 & 14.5 & 0.7 \\
\hline $\mathrm{LL}$ & $10 / 20 / 2003$ & 5.1 & 35.3 & 1.8 \\
\hline
\end{tabular}

Mary Lynam, Elizabeth Malcolm, Jim Barres, Ann Krueger, Tamar Krantz, Kristie Mukherjee, Elizabeth Esseks, Julie Peterson, Minghao Zhou, and Ali Kamal. This work would not have been possible without the dedication of the site scientists and operators Carl Waite and Miriam (Mim) Pendleton. We would also like to thank our collaborators at the State of Vermont, USEPA, NOAA, and NESCAUM, including Rich
Poirot, Rick Artz, Roland Draxler, Alan Van Arsdale, Lee Alter, and Margaret Round for their dedication and support. Lastly, we would like to thank the reviewers for their insightful comments which significantly improved the quality of this manuscript.

\section{References}

Bloom, N.S. and Watras, C.J. (1989). Observations of methylmercury in precipitation. Sci. Total Environ. 87/88, 199.

Bradley, R.S. (1986). Uncertainties in Trends in Acid Deposition: The role of climatic fluctuations. Acid Deposition Long-Term Trends, pp. 93-. Washington, D.C.: National Academy Press.

Burke, J., Hoyer, M., Keeler, G. and Scherbatskoy, T. (1995). Wet deposition of mercury and ambient mercury concentrations at a site in the Lake Champlain basin. Water Air Soil Pollut. 80, 353-62.

Butler, T.J. and Likens, G.E. (1991). The impact of changing regional emissions on precipitation chemistry in the eastern United States. Atmos. Environ. 25A, 305-15.

Butler, T.J., Likens, G.E. and Stunder, B.J. (2001). Regionalscale impacts of Phase I of the Clean Air Act Amendments in the USA: the relation between emissions and concentrations, both wet and dry. Atmos. Environ. 35, 1015-28.

Church, T.M., Tramontano, J.M., Scudlark, J.R., Jickells, T.D., Tokos, J.J., Knap, A.H. and Galloway, J.N. (1984). Atmos. Environ. 18, 2657.

Draxler, R.R. and Hess G.D. (1997). Description of the HYSPLIT_4 Modeling System. NOAA TECHNICAL MEMORANDUM ERL ARL-224.

Dvonch, J.T., Graney, J.R., Keeler, G.J. and Stevens, R.K. (1999). Utilization of Elemental Tracers to Source Apportion Mercury in South Florida Precipitation. Environ. Sci. Technol. 33, 4522-27.

Fitzgerald, W.F., Mason, R.P. and Vandal, G.M. (1991). Atmospheric cycling and air-water exchange of mercury over mid-continental lacustrine regions. Water Air Soil Pollut. 56, 745.

Hoyer, M.E., Burke, J.B. and Keeler, G.J. (1995). Atmospheric sources, transport and deposition of mercury in Michigan: two years of event precipitation. Water Air Soil Pollut. 80, 199-208.

Iverfeldt, A. (1991). Occurrence and turnover of atmospheric mercury over the Nordic countries. Water Air Soil Pollut. 56, 553.

Iverfeldt, A. and Lindqvist, O. (1986). Atmospheric oxidation of elemental mercury by ozone in the aqueous phase. Atmos. Environ. 20, 1567-73.

Kamman, N. and Engstrom, D. (2002). Historical and present fluxes of mercury in Vermont and New Hampshire lakes inferred from $\mathrm{Pb} 210$-dated sediment cores. Atmos. Environ. 36, 1599-610.

Keeler, G.J., Hoyer, M.E. and Lamborg, C.H. (1994). In C.J. Watras and J.W. Huckabee (eds). Mercury Pollution: Integration and Synthesis, pp. 231-41. Boca Raton, FL: Lewis Publishers. 
Keeler, G.J. and Hoyer, M.E. Atmospheric mercury in the Great Lakes Region. In: Atmospheric Deposition of Contaminants to the Great Lakes and Coastal Waters. (Baker, J. Ed.), SETAC Sponsored Book, Lewis Publishers, N.Y., 1997.

Keeler, G.J. and Dvonch, J.T. (2004). Atmospheric Mercury: A Decade of Observations in the Great Lakes In N. Pirrone and K. Mahaffey (eds). Dynamics of Mercury Pollution on Regional and Global Scales: Atmospheric Processes and Human Exposures around the World: Kluwer Ltd.

Landis, M.S. and Keeler, G.J. (1997). A critical evaluation of an automatic wet-only precipitation collector for mercury and trace element determinations. Environ. Sci. Technol. 31, 2610-15.

Lin, C.J. and Pehkonen, S.O. (1999). The chemistry of atmospheric mercury: a review. Atmos. Environ. 33, 2067-79.

Lindqvist, O. and Rodhe, H. (1985). Atmospheric mercury - a review. Tellus 37B, 134.

Malcolm, E.G., Keeler, G.J., Lawson, S.T. and Sherbatskoy, T.D. (2003). Mercury and trace elements in cloud water and precipitation collected on Mt. Mansfield, Vermont. $J$. Environ. Mon. 4, 584-90.

McIntosh, A. (1994) Lake Champlain Sediments Toxics Assessment Program. An assessment of sediment associated contaminants in Lake Champlain-Phase I, UVM School of Natural Resources.

Miller, E.K., VanArsdale, A., Keeler, G.J., Chalmers, A., Poissant, L. and Kammen, N. (2005). Estimation and Mapping of Wet and Dry Mercury Deposition across Northeastern North America. Ecotoxicology 14, .

Mierle, G. (1990). Aqueous inputs of mercury to precambrian shield lakes in Ontario. Environ. Toxicol. Chem. 9, 843-51.

New England Governors and Canadian Premiers (2003). Report to the New England Governors and Eastern Canadian Premiers in mercury projects. August 2003.
Poirot, R.L., Wishniski, P.R., Hopke, P.K. and Polissar, A.V. (2001). Environ. Sci. Technol. 35, 4622-36.

Ross, H.B. (1986). The importance of reducing sample contamination in routine monitoring of trace metals in atmospheric precipitation. Atmos. Environ. 20, 401.

Ross, H.B. (1990). Trace metal wet deposition in Sweden: insight gained from daily wet only collection. Atmos. Environ. 24A, 1929.

Scherbatskoy T., Burke J., Rea A. and Keeler G.J. (1994). Atmospheric mercury deposition and cycling in the Lake Champlain Basin of Vermont. Atmospheric Deposition of Contaminants to the Great Lakes and Coastal Waters. Proceedings from the SETAC 15th Annual Meeting. Edited by J. Baker. 245-57.

Scherbatskoy, T., Shanley, J. and Keeler, G.J. (1998). Factors controlling mercury transport in an upland forest catchments. Water Air Soil Pollut. 105, 427-38.

Schroeder, W.H. and Munthe, J. (1998). Atmospheric mercuryan overview. Atmos. Environ. 32, 809.

Scudlark J.R., Church T.M., Conko K.M. and Moore S.M. (1991). A method for the automated collection, proper handling and accurate analysis of trace metals in precipitation. U.S. Forest Service Report NC-150, Symposium Proceedings, Philadelphia, PA. 57-71.

Sisterson, D.L., Wurfel, B.E. and Lesht, B.M. (1985). Chemical differences between event and weekly precipitation samples in northeastern Illinois. Atmos. Environ. 19, 1453.

Subramanian, K.S., Chakrabarti, C.L., Sueiras, J.E. and Maines, I.S. (1978). Preservation of some trace metals in samples of natural waters. Anal. Chem. 50, 444.

VanArsdale, A., Weiss, J., Keeler, G.J. and Miller, E. (2005). Patterns of mercury deposition in northeastern North America (1996-2002). Ecotoxicology 14, 